\title{
The State of Affairs and Prospects of Application of Special Knowledge in the Investigation of Financial Criminal Offences
}

\section{Gerasymenko Larysa}

PhD of Juridical Sciences, Associate Professor, Head of Department of Economic Security and Financial Investigations of the National Academy of Internal Affairs, Kiev, Ukraine ORCID ID 0000-0001-6340-1061 lora-gera@ukr.net

\section{Morhun Nadiia}

PhD of Juridical Sciences, Professor of Department of Economic Security and Financial Investigations of the National Academy of Internal Affairs, Kyiv, Ukraine

ORCID ID 0000-0002-2997-9975 Morgun.nadiy@gmail.com

\section{Pavlovska Nataliia}

PhD of Juridical Sciences, Associate Professor, Professor of Department of Civil Law and Process of the National Academy of Internal Affairs, Kiev, Ukraine ORCID ID 0000-0003-3311-0364 wwwpav@gmail.com

\section{Marchevskyi Sergiy}

PhD of Juridical Sciences, Associate Professor of Department of Economic Security and Financial Investigations of the National Academy of Internal Affairs, Kyiv, Ukraine ORCID ID 0000-0002-3623-4461 marik1984@ukr.net

\section{Shevchuk Oleksandr}

PhD of Juridical Sciences, Associate Professor of Department of Economic Security and Financial Investigations of the National Academy of Internal Affairs, Associate Professor Kyiv, Ukraine ORCID ID 0000-0002-5513-6517 alexosvita@ukr.net

\footnotetext{
Abstract

Special knowledge means specific knowledge, not considered common knowledge, on the phenomena, objects and processes in the surrounding world possessed by a particular group of people. Special knowledge is based on scientific findings and cannot be common knowledge. Special knowledge is acquired through purposeful professional training and practical experience in a particular sphere; they constitute a system of knowledge about specific objects, phenomena and patterns studied within a relevant scientific field.

Keywords: financial crime, economic security, financial investigations, special knowledge, expert, specialist, forensic examination.
} 
Introduction Special knowledge is scientific, technical or practical knowledge which is not common knowledge in legal proceedings and is obtained in the course of professional training or employment in a specific field by individuals involved as professionals or experts to assist an investigation or a trial in identifying the circumstances of the case or providing opinions on issues where it is necessary to apply such knowledge. The Criminal Procedure Code of Ukraine (the CPC) provides for the application of special knowledge of experts and specialists as a source of evidence giving both prosecution and defence vast opportunities to use them in the evidentiary process. In terms of procedural regulation, special knowledge is applied in criminal proceedings in the following forms: the procedural form (involvement of specialists during investigative (detective) actions; forensic examinations ordering; questioning of experts in court); the non-procedural form (inspections, audits, use of special knowledge by investigators, prosecutors, judges and lawyers, oral consultations provided by experts and specialists); the mixed form (advice and guidance in criminal proceedings, verification based on criminal records, explanatory notes written by specialists).

Such forms also correspond to the forms of applying special knowledge during the investigation of financial criminal offences.

The following forensic examinations can be ordered while investigating financial criminal offences: 1) handwriting examination; 2) questioned document examination; 3) examination of weapons, their traces and circumstances of their use (forensic firearm examination); 4) handprint examination (fingerprint analysis); 5) analysis of trace materials; 6) examination of photographic equipment and materials; 7) forensic facial identification; 8) forensic video- and audio analysis; 9) forensic analysis of explosives; 10) examination of materials, substances and products; 11) computer and software examination; 12) economic expert analysis; 13) forensic merchandise analysis, etc.

When appointing a particular forensic examination in a criminal proceeding on a financial offence, investigators use specialists to take samples and formulate questions and receive their guidance and advice on other issues (related to packing items, their storage, transportation conditions, etc.).

A forensic handwriting examination makes it possible to identify the authors of handwritten texts, handwritten notes (consisting of letters and numbers) and signatures. 
Original documents should be provided to execute handwriting examination of handwritten notes and signatures [1].

This expert examination addresses the following main issues arising in cases on financial criminal offences: whether a specific individual is an author of a handwritten text in a document; whether a single individual is the author of handwritten texts in a document; whether a document is signed by the individual whose name the signature bears, or by another individual.

Questioned document examination This examination is of the following types: an examination of document details, an examination of printing forms, an examination of materials of documents.

The main objectives of the technical examination of document details performed in cases regarding financial criminal offences are establishing the facts and methods of making changes to and identifying their original content. Original documents should be provided to perform an examination to establish the fact of making changes to the original content of documents; detection of texts on various materials, which are damaged by liquids, painted over, discoloured and otherwise weakly visible or invisible, as well as texts on scorched and burntout documents, provided that the paper on which they are depicted has not turned to ashes; identifying writing tools and their types by strokes; determining relevant recentness of execution of a document or its fragments and the sequence of intersecting strokes; reconstruction of a document from its parts; reconstruction of a document pasted up with the use of copying machines and computers [1].

To identify documents created on computers, relevant equipment should be provided as a set. It is prohibited to perform any works on computers prior to their examination. Identification is performed within a comprehensive computer and technical examination and a questioned document examination if an electronic original document is available. Computer equipment should be seized and inspected in the presence of a computer specialist.

The main objectives of the examination of printing forms performed in cases on financial criminal offences are the following: identifying the computer and copying equipment and their types on the basis of material documents produced by them; establishing the way impressions of seals, stamps or facsimiles have been made; identification of seals, stamps, facsimiles, etc. by their impressions; compliance between the time when impressions of seals 
or stamps were actually made and the document creation dates. Original documents should be provided to examine documents to identify seal or stamps (and facsimiles in particular) and establish whether the times when impressions of seals or stamps were made correspond to the document creation dates.

Hand traces examination. Its main objective is to identify individuals by their handprints left on the scene. Fingerprint analysis performed in criminal proceedings on financial offences provides answers to the questions: whether there are handprints on the object; whether a specific and single individual left handprints; whether a single individual left handprints collected in various places; whether there are handprints on a particular object and if so, whether they are suitable for identification; which hand and which fingers left traces; which action left an imprint; whether there were traces on the surface of a particular object before collection.

Forensic facial identification. The primary objective of forensic facial identification is to identify an individual on the basis of photos and video records. The main issues that need to be resolved through it while investigating financial criminal offences are the following: whether a specific photo shows a person, whose photos (videos) have been provided as samples and whether the same individual or different people are present in specific photos (videos). Authentic (amateur, professional, or experimental) photos and videos of an individual can serve as comparative materials for identifying such a person on the basis of photographs. It is desirable that images similar to the examined one by shooting time and camera angle be present among the comparative samples.

Forensic video- and audio analysis. The forensic video- and audio analysis performed in criminal proceedings on financial offences has two main groups of objectives:

1) identification of technical conditions and technologies used in video and audio recording, in particular, whether a video material and its fragments was recorded by a specific device; whether specific fragments of the video (audio) material were recorded by one or more devices; whether the provided videomaterial was the original or a copy; whether the video material was recorded without intermission; whether the provided video (audio) material underwent changes; whether the video image and sound of the video material were recorded simultaneously and whether the content of the image corresponds to the sound recording; which video (audio) materials contain areas where information from devices (a digital voice recorder, other video or audio recording devices, etc.) has been deleted and whether it is possible to recover in full or in part a video (audio) track from a removable medium; 
2) identifying a person by physical properties of his or her voice: how many people took part in the conversation recorded, whether the listed persons were involved in the conversation recorded and what specific words and phrases they said.

The following items should be provided for examination to identify the technical conditions and technologies of video and audio recordings: the original video (audio) material; the original device which recorded the material; additional equipment, in full, used in the material recording: a microphone, a power-supply source, control devices, etc.; exhaustive information on what engineering changes if any have been made to the recording device and additional equipment. Experts should be provided with audio materials containing comparable samples of conversations (dialogues or monologues) to identify individuals by their oral speech recorded in the examined material. A transcript of listening for the audio material must also be provided with printed texts of conversations.

Forensic analysis of explosives The analysis of explosives performed during the investigation of their theft, misappropriation or extortion by an official through abuse of his or her office serves the following objectives: establishing the fact that a particular item is explosive; identifying how the explosives were made; determining whether the explosives found in specific places belong to the same type (group).

Examination of materials, substances and products involves studying special chemicals; narcotics, psychotropic substances, their analogues and precursors; superpotent and toxic substances; soils, etc. This examination makes it possible to detect microparticles or microtraces of certain materials and substances on the items on the scene and establish whether materials and substances belong to the same type. In particular, if a specialist treats an item of illegal benefit with special chemicals and their traces are then detected on the hands of the bribetaker, the examination of materials, substances and products should answer the following questions: whether there are layers of special chemicals on carriers (banknotes, hand swabs, etc.); what is the nature of the substance provided for examination and whether the provided substances belong to the same group.

Computer and software examination. In criminal proceedings on financial criminal offences, a computer and software examination may perform the following functions: identifying under which circumstances computers, information and software were used and detecting information and software on computer media [2]. 
Forensic economic expert analysis is performed in cases related to financial criminal offenses, involving analysing accounting and reporting and tax accounting and reporting documents; analysing documents related to business operations of enterprises and organizations; analysing documents related to financial and credit operations:

1) analysing accounting and reporting and tax accounting and reporting documents can determine whether the amounts of shortage or surplus of inventory items and cash are properly documented and the time and place of their formation; whether registration of reception, storage, manufacturing and disposal of inventory items and, in particular, monetary items, fixed assets and services are properly documented; whether income and expenses related to financial and economic transactions subject to income tax are documented in the tax accounting in compliance with laws and regulations;

2) the expert analysis of documents related to business operations of enterprises and organizations serve the primary purposes of determining whether settlements with debtors and creditors, cost structure analysis and targeted budget funds spending are properly documented;

3) the expert analysis of financial and credit transactions serves to determine whether account opening registrations, cash flows on accounts [3], registration and accounting by banks of their financial and economic operations [4] and deposit transactions of banking and other financial institutions are properly documented [1].

Forensic merchandise analysis is ordered, in particular, with regard to military materiel, when theft or misappropriation by military officials of vehicles, military and special equipment or other military property is investigated. This analysis serves to identify the value of items used as military materiel and submitted for examination; types and purposes of items submitted for analysis; characteristics and properties of such items under the Ukrainian classifier of goods for foreign economic operations; manufacturers, countries of origin, years of manufacture of such items; changes in the quality indicators of such items.

Conclusions Special knowledge is considered professional knowledge and skills in science, technology, arts or crafts, necessary to address issues arisen during financial investigations and judicial review of specific cases [5]. Two main approaches to the concept of "special knowledge" in criminal proceedings are applied scientifically depending on the individuals that use them. 
1) Special knowledge is knowledge in a certain field of science, technology, art or craft, etc., applied by participants in criminal proceedings as part of their remit (broader term). Individuals applying such knowledge may include investigators, prosecutors, judges or lawyers.

2) Special knowledge is knowledge used by experts or specialists during examinations or while participating in investigative (detective) measures (narrower term).

\section{References}

1. On approval of the Instruction on ordering and performance of forensic examinations and expert research and the Scientific and methodological recommendations on preparation and ordering of forensic examinations and expert research : Order of the Ministry of Justice of Ukraine dated October 8, 1998, № 53/5. URL: https://zakon.rada.gov.ua/laws/show/z0705-98

2. On approval of the Instruction on the procedure for involving employees of pretrial investigation bodies of the police and the Expert Service of the Ministry of Internal Affairs of Ukraine as specialists to participate in scene examinations : Order of the Ministry of Internal Affairs of Ukraine of 3 November 2015, No. 1339.

URL: https://zakon.rada.gov.ua/laws/show/z1392-15

3. Bilenchuk, P. D., Kofanov, A. V., Kobylianskyi, O. L. Computer crimes in the credit and finance industry: a criminalistic analysis. A manual. Edited by P. D. Bilenchuk. Kyiv, KYI, 2011.

4. Bilenchuk, P. D., Kofanov, A. V., Kobylianskyi, O. L., Tsapko, V. Ye. The legal status and organisation and management principles of the State Treasury of Ukraine. A manual. Edited by P. D. Bilenchuk. Kyiv, KYI, 2011.

5. Problems and perspectives for attracting investments in economy of Ukraine. URL: https://doi.org/10.21511/imfi.16(2).2019.17 